JUSTYNA KIJONKA

\author{
III

\section{GÓRNOŚLAZZACY. TOŻSAMOŚĆ REGIONALNA I ETNICZNA PONAD GRANICAMI}

ABSTRACT. Justyna Kijonka, Górnoślqzacy. Tożsamość regionalna i etniczna ponad granicami [Upper Silesians. Regional and ethnic identity across borders] edited by E. Smolarkiewicz, J. Kubera ${ }_{\prime \prime}$ Człowiek i Społeczeństwo"vol. XLIV: Tożsamość iidentyfikacje. Propozycje teoretyczne - doświadczenia badawcze [Identity and identifications. Theoretical proposals - research experiences], Poznań 2017, pp. 111-131, Adam Mickiewicz University. Faculty of Social Sciences Press. ISSN 0239-3271.

Silesian identity is what connects regardless of national identity. The aim of this article is to present the problem of identity of Upper Silesians living in Poland and in Germany in the context of conception of the imaginary community and transnational theory. The issues of the social worlds in which Upper Silesians live in Poland and in Germany will also be tackled. The paper is based on research devoted to the Upper Silesian identity, which I have been conducting for several years in Poland, and recently also in Germany.

Justyna Kijonka, Uniwersytet Śląski w Katowicach, Instytut Socjologii, ul. Bankowa 11, 40-007 Katowice, e-mail: justyna.kijonka@us.edu.pl

\title{
Wstęp
}

Górnoślązacy - zarówno mieszkający na Górnym Śląsku jak i ci, którzy mieszkają obecnie poza regionem pochodzenia - zazwyczaj bardzo silnie się z nim identyfikują, traktując go jako swoją ojczyznę prywatną. Nierzadko więc tożsamość o charakterze etnicznym i regionalnym jest tą dominującą. Może ona stać się do tego stopnia znacząca, że będą uważali się za członków odrębnego, śląskiego narodu. Jedni uczynią to w opozycji do tożsamości narodowej - polskiej, niemieckiej czy, rzadziej, czeskiej. 
Inni poprzez deklarowanie narodowości śląskiej będą podkreślać szczególnie silne przywiązanie do regionu, jego kultury, a także - co w tym kontekście szczególnie godne podkreślenia - przynależność do górnośląskiej wspólnoty pamięci. Jeszcze inni będą podkreślać swe polskie i śląskie korzenie; spotkamy też Górnoślązaków akcentujących swą rodowitą śląskość i niemieckość. Będą wreszcie Górnoślązacy - zwykle mieszkający od wielu lat w Niemczech - bez tożsamości narodowej, mówiący o sobie, że są Europejczykami. Ta różnorodność postaw sprawia, że to, co zwykle określa się mianem górnośląskiej tożsamości, jest zjawiskiem złożonym i wielowymiarowym. Nie ma tym samym jednej tożsamości górnośląskiej. Czym innym jest bowiem, jak się wydaje, bycie Górnoślązakiem w Polsce, a czym innym w Republice Federalnej Niemiec.

W artykule poruszony został problem tożsamości Górnoślązaków mieszkających zarówno w Polsce, jak i tych, którzy zdecydowali się na emigrację do Niemiec na podstawie dokumentów dających prawo do niemieckiego obywatelstwa. Materiał empiryczny pochodzi z kilku indywidualnych projektów badawczych przeprowadzonych przeze mnie w Polsce ${ }^{1}$ i w Niemczech ${ }^{2}$ oraz z projektów, w których uczestniczyłam jako członek zespołu badawczego ${ }^{3}$. Odwołuję się także do bogatej literatury przedmiotu;

${ }^{1}$ W latach 2007-2008 prowadziłam badania do pracy doktorskiej - wywiady z osobami deklarującymi narodowość śląską, z laureatami konkursu na monologi w gwarze śląskiej „Po naszymu, czyli po śląsku” oraz wywiady z wybitnymi Ślązakami i działaczami organizacji regionalnych. Wyniki tych badań zaprezentowałam i omówiłam w książce Tożsamość współczesnych Górnoślq̨zaków. Studium socjologiczne.

${ }^{2}$ W 2012 r. realizowałam projekt „Migrationen aus der Woiwodschaft Kattowitz in die Bundesrepublik Deutschland in den Jahren 1970-1989. Eine soziologische Studie” („Migracje z województwa katowickiego do Republiki Federalnej Niemiec w latach 1970-1989. Studium socjologiczne”) w ramach stypendium bibliotecznego w Deutsches Polen-Institut w Darmstadt. Celem projektu bibliotecznego było opracowanie stanu badań i przygotowanie projektu przyszłych badań empirycznych, które zostały przeprowadzone w ramach indywidualnego projektu podoktorskiego „Die Welten der (Spät-) Aussiedler aus Oberschlesien in der Bundesrepublik Deutschland” („Światy społeczne «wysiedleńców» i «późnych wysiedleńców» w Republice Federalnej Niemiec”) w czasie pobytu na Uniwersytecie Johanna Wolfganga Goethego we Frankfurcie nad Menem. Stypendium sfinansowane zostało przez Niemiecką Centralę Wymiany Akademickiej (DAAD). Badania realizowane były od października 2014 do lipca 2015 r. W ramach tych badań przeprowadziłam ponad dziewięćdziesiąt wywiadów i rozmów. Były to wywiady głównie z osobami, które w latach 1970-2000 wyjechały do Niemiec i uzyskały status „wysiedleńca”.

${ }^{3}$ W roku 2007 Zakład Socjologii Rozwoju pod kierunkiem Marka S. Szczepańskiego przeprowadził badania zatytułowane „Między regulacją a spontanicznością. Przemiany 
przywołuję również konteksty historyczno-kulturowe, ponieważ tożsamość górnośląska i przywiązanie do regionu jest tym, co łączy Górnoślązaków różnych opcji narodowych, mających także różne stanowiska dotyczące przeszłości regionu oraz odmienne wizje przyszłości Górnego Śląska. Tekst stanowi zatem uogólnioną refleksję nad górnośląską tożsamością w Polsce i w Niemczech. Terminy „Ślązak” i „Górnoślązak” traktowane są przeze mnie jako synonimy, tym samym używam ich w artykule zamiennie.

\section{Socjologia tożsamości w śląskim narożniku}

Tożsamość narodowa i etniczna mieszkańców Górnego Śląska, a także kwestie związane z labilnością narodową Górnoślązaków były przedmiotem refleksji o charakterze socjologicznym już w okresie II RP. Dlatego też warto w tym miejscu wspomnieć tradycję refleksji i badań nad górnośląską tożsamością. Przykładem międzywojennych badań poświęconych kwestiom tożsamościowym jest praca Józefa Chałasińskiego Antagonizm polsko-niemiecki w osadzie fabrycznej „Kopalnia” na Górnym Ślqcsku. Studium socjologiczne. Powstawały także klasyczne już rozprawy i rozważania teoretyczne dotykające tego problemu, by wymienić tylko rozprawę Emila Szramka Śląsk jako problem socjologiczny. Co istotne, już w pierwszych pracach o charakterze socjologicznym poświęconych Górnemu Śląskowi zwracano uwagę na położenie geograficzne ${ }^{4}$ i związane $\mathrm{z}$ tym konsekwencje dla tożsamości mieszkańców regionu. To położenie właśnie sprawiało, że w regionie nie

ładu społecznego w okresie transformacji systemowej. Przypadek województwa śląskiego". Razem z Adamem Bartoszkiem i Tomaszem Nawrockim przeprowadziłam w grudniu 2008 r. badania zatytułowane „Ja Ślązak, ja Polak, ja Europejczyk”, finansowane ze źródeł Programu Operacyjnego „Patriotyzm jutra” na reprezentatywnej próbie uczniów szkół ponadgimnazjalnych województwa śląskiego. Projekty te poświęcone były nie tylko problemom tożsamości Górnoślązaków, jednak pojawiały się w nich kwestie identyfikacji mieszkańców regionu.

${ }^{4}$ Emil Szramek w 1934 r. pisał: „Śląsk stanowi pod względem geograficznym rodzaj narożnika i od wieków dzieli los wszystkich narożników, że się mianowicie o nie zawadza i w nie uderza. Każde zderzenie zaś i ciśnienie powoduje ruch bądź to zewnętrzny, czyli zmianę położenia, bądź to wewnętrzny, wytwarzający ciepło, które albo wiąże albo rozsadza” (Szramek 1934: 24). Z kolei Rybicki w 1938 r. zwracał także uwagę na położenie regionu, przez co w opinii socjologa był on „z natury swego położenia bardziej od innych dzielnic eksponowany na wpływy ziem i społeczeństw obcych” (Rybicki 1938: 30-31), tym samym „położenie graniczne zmieniało się stopniowo w sytuację pogranicza” (Rybicki 1938: 30-31). 
brakowało osób labilnych narodowo i o złożonej tożsamości narodowo-etnicznej, owych „grusz granicznych rodzących na obie strony”, by użyć metafory Szramka ${ }^{5}$. Wybitny polski socjolog pełniący także funkcję dyrektora Biblioteki Śląskiej w Katowicach Paweł Rybicki pod koniec lat trzydziestych XX w. w pracy O badaniu socjograficznym Ślq̨ska zauważył, że to właśnie zawiłe relacje narodowościowe i nakładające się na nie nierówności społeczne stanowią jeden z tych elementów społecznych, które wyróżniają ten region jako przedmiot badań socjologicznych. Co istotne, w swej refleksji zwracał uwagę na perspektywę długiego trwania (Rybicki 1938: 30-31).

Po roku 1945, będącym datą graniczną polskiej rzeczywistości, wyłoniły się problemy społeczne, które są nadal żywe, a które ściśle wiążą się z położeniem geograficznym Górnego Śląska i o których pisali w swych analizach Szramek i Rybicki. Państwo polskie w nowych, powojennych granicach zmieniło usytuowanie Górnego Śląska, co wpłynęło w zasadniczy sposób na losy oraz tożsamość narodową i etniczną jego ludności, zwłaszcza rodzimej. Do tego Polacy w latach wojny i powojennych stali się ,narodem na walizkach”, by użyć sugestywnej metafory Krystyny Kersten (Kersten 1986: 704). Masowe wysiedlenia ludności niemieckiej przy jednoczesnej weryfikacji osób, które zdecydowały się pozostać w swej małej ojczyźnie, oraz spotkanie z odmiennymi kulturowo repatriantami z Kresów Wschodnich miały znaczący wpływ na przebieg procesów tożsamościowych wśród ludności rodzimej Górnego Śląska. Ponadto do czasu podpisania układu normalizacyjnego między PRL a RFN pod koniec 1970 r. zachodnia granica Polski była niepewna, panowało poczucie, że tereny te znajdują się w granicach Polski tylko przejściowo. W opinii ludności rodzimej to Górny Śląsk, w przeciwieństwie do państwa i pojęcia narodu, był czymś stabilnym, niezmiennym, co zauważył jeden z rozmówców Stanisława Ossowskiego ze Śląska Cieszyńskiego: „narodowość może się zmienić, górnośląskość pozostanie" (Ossowski 1984: 124). Ten ton pojawia się nadal w wypowiedziach starszych rozmówców z Górnego Śląska, będących świadkami tamtych czasów i wydarzeń, a mieszkających obecnie zarówno w Polsce, jak i w Niemczech. To przywiązanie do ojczyzny prywatnej, by posłużyć

${ }^{5}$ Szramek w rozprawie z 1934 r. zauważa, że „są jednostki nie tylko dwujęzyczne, ale też podwójnego oblicza narodowego, podobne do kamieni granicznych, które z jednej strony noszą znamię polskie, z drugiej niemieckie, albo do gruszy granicznych, które na obie strony rodzą. Nie są to ludzie bez charakteru, lecz ludzie o charakterze granicznym” (Szramek 1934: 35). I dalej: „Zjawiskiem typowo granicznym są ludzie o chwiejnej równowadze narodowej, wiecznie niezdecydowani, istne trzciny, które pod powiewem lada wietrzyka przechylają się to w tę, to w ową stronę” (Szramek 1934: 37). 
się terminem Ossowskiego, owa „górnośląskość” jest synonimem stabilności w sytuacji, gdy trzeba dokonywać wyborów narodowościowych, które nierzadko dzielą rodziny i są przyczyną prywatnych dramatów.

Mimo że do roku 1989 nie podejmowano szerszych badań empirycznych nad tożsamością mieszkańców regionu, pojawiały się w tym czasie interesujące studia o charakterze historycznym ${ }^{6}$. Z kolei czas po tej dacie granicznej społecznych i politycznych przemian otwiera szeroki nurt dyskusji nad śląską tożsamością. Co szczególnie ważne, także w tym okresie powstają organizacje regionalne, takie jak Związek Górnośląski czy Ruch Autonomii Śląska. Doszło również do powołania kilku organizacji mniejszości niemieckiej, w tym Towarzystwa Społeczno-Kulturalnego Niemców czy Niemieckiej Wspólnoty „Pojednanie i Przyszłość”. W późniejszym czasie dochodzi do sporów i politycznej walki o uznanie narodowości śląskiej, dyskutowane są także wyniki spisów powszechnych.

Wszystko to stało się przedmiotem badań naukowych i refleksji socjologicznej, a samych studiów poświęconych tej problematyce powstało wówczas wiele. Na procesy społeczne, które miały wtedy miejsce, a w konsekwencji pojawienie się prac naukowych poświęconych tej problematyce, zwrócił uwagę Jacek Wódz, pisząc, że „owo odrodzenie się tradycji rozpoczyna się od elementów kulturowych, w których szczególną rolę odgrywa przestrzeń symboliczna, jako nośnik przekazu kulturowego mającego charakter regionalny. [...] Następnym etapem jest powstawanie rewindykacji politycznych, co stanowi [...] naturalny element ewolucji poczucia przynależności regionalnej w społeczeństwie otwartym, demokratycznym, w którym owo poczucie przynależności wyraża się w organizowaniu się wokół wspólnych interesów regionalnych” (Wódz 2001: 37).

Po przełomie ustrojowym rozpatrywano tożsamość śląską w różnych jej aspektach, analizowano poczucie tożsamości regionalnej, kulturowej i etnicznej Górnoślązaków. Jednak zainteresowanie badaczy skupiało się przede wszystkim na Górnoślązakach mieszkających w Polsce, zwłaszcza na Górnym Śląsku. Górnoślązacy mieszkający w Niemczech byli przedmiotem uwagi badaczy będących - z oczywistych względów przedstawicielami niemieckich nauk społecznych. Prac poświęconych migracjom Górnoślązaków powstało po 1989 r. stosunkowo niewiele

${ }^{6}$ Do ważnych prac z tego obszaru należy książka Eugeniusza Kopcia „My i oni” na polskim Ślq̨sku, podejmująca temat stosunków etnicznych na Śląsku w okresie międzywojnia.

7 Należałoby tu wymienić przede wszystkim książkę Aleksandry Trzcielińskiej-Polus „Wysiedleńcy” z Polski w Republice Federalnej Niemiec w latach 1980-1990 (1997). 
Zjawisko wyjazdów do Niemiec ludności Górnego Śląska analizowane było głównie w latach siedemdziesiątych i osiemdziesiątych ubiegłego wieku, a więc w czasach masowej emigracji ${ }^{8}$. Zainteresowanie polskich badaczy tymi, którzy w XIX w. wyemigrowali z terenów dzisiejszego Śląska Opolskiego do Brazylii i Teksasu, należy do innej kategorii studiów. Można odnaleźć pewne analogie między tamtymi wyjazdami a migracjami po 1970 r., ponieważ procesy migracyjne przebiegają zwykle wedle pewnych schematów. Warto w tym miejscu zaznaczyć, że XIX-wieczne migracje zamorskie Górnoślązaków mają jednak wpływ na kształtowanie się górnośląskiej wspólnoty wyobrażonej ${ }^{9}$.

\section{Problem statystyk}

Tożsamość regionalna i etniczna Górnoślązaków przybiera współcześnie różne postaci - od identyfikacji kulturowej i etnicznej, mającej charakter prywatny, poprzez spisowe deklaracje, aż po publiczne podkreślanie swojej odrębności, przyjmujące nawet charakter politycznej deklaracji. Wyniki obu spisów pokazały dobitnie istnienie osób deklarujących się jako „Ślązacy”. Jednak dopiero badania socjologiczne ${ }^{10}$ i wywiady z tymi osobami pokazały motywy ${ }^{11}$ spisowych deklaracji i pozwoliły w pewien sposób na opisanie tej grupy. W spisie powszechnym z 2002 r. było 173200 osób deklarujących narodowość śląską. W kolejnym spisie z roku 2011 pojawiła się już możliwość deklarowania kilku narodowości. Wtedy to ponad 846700 zadeklarowało narodowość śląską, w tym 435800 jako pierwszą, 375600 jako jedyną, zaś 411000 jako identyfikację drugą. Narodowość

${ }^{8}$ Na szczególną uwagę zasługują między innymi prace Jana Korbla: Wyjazdy i powroty: migracje ludności w procesie normalizacji stosunków między Polskq a RFN (1977) i Emigracja z Polski do RFN: wybrane problemy (1986) oraz Zdzisława Łempińskiego RFN wobec problemów ludnościowych w stosunkach z Polskq (1970-1985) (1986).

${ }^{9}$ Warto wspomnieć spektakl Western, który miał swoją premierę w Teatrze Śląskim w $2015 \mathrm{r}$.

${ }^{10}$ Wspomnieć należy tu przede wszystkim dwie książki oparte na badaniach z deklarującymi się jako „Ślązacy” - Być narodem? Ślqzacy o Ślq̨sku Elżbiety Anny Sekuły, Bohdana Jałowieckiego, Piotra Majewskiego i Waltera Żelaznego (2012) oraz Tożsamość współczesnych Górnoślq̨zaków. Studium Socjologiczne Justyny Kijonki (2016).

${ }^{11}$ Po ogłoszeniu wyników z kolei analizowano szeroko również przyczyny śląskich spisowych deklaracji. Marek S. Szczepański zwracał uwagę na pięć motywów deklaracji narodowości śląskiej: autentyczną tożsamość, rozczarowanie restrukturyzacją przemysłu, potrzebę katharsis, wynik działalności między innymi Ruchu Autonomii Śląska oraz cele polityczne regionalnych działaczy (Szczepański 2003). 
śląską występującą razem z narodowością polską zadeklarowało wówczas 430798 osób. Te podwójne kategorie mówią wiele o złożoności tożsamościowych wyborów Górnoślązaków. Trudno jest zatem jednoznacznie stwierdzić, ilu jest rzeczywiście Górnoślązaków, pamiętać bowiem należy, że nie wszyscy utożsamiający się ze śląskością deklarują narodowość śląską oraz że deklarowana bywa ona także przez osoby, które nie są rodowitymi Górnoślązakami, a które z tym regionem silnie się utożsamiają. Do tego bez odpowiedzi pozostanie pytanie, ile takich osób mieszka na stałe w Republice Federalnej Niemiec, gdzie Ślązacy wyjeżdżali masowo w kolejnych falach powojennych migracji. W tym drugim przypadku pozostanie ono najprawdopodobniej bez odpowiedzi.

Fakt deklarowania narodowości śląskiej podczas pierwszego ze spisów był bardzo dużym zaskoczeniem, co znalazło swe odbicie w doniesieniach medialnych, w których nie uwzględniano faktu, iż badania socjologiczne prowadzone od lat dziewięćdziesiątych ubiegłego stulecia pokazują dobitnie, że istniała jeszcze przed spisem grupa osób deklarujących się wyłącznie jako Ślązacy ${ }^{12}$. Także drugi spis wywołał dyskusję z jednej strony ze względu na otwartą możliwość deklarowania narodowości śląskiej, z drugiej zaś - ze względu na przyjętą metodologię. Co istotne, brały już w nim udział roczniki młodsze, które ze względu na wiek nie mogły uczestniczyć we wcześniejszym spisie. O tym, jak silna była i zapewne jest nadal identyfikacja z regionem młodszych generacji, pokazują badania przeprowadzone w 2008 r. na reprezentatywnej próbie młodzieży szkół gimnazjalnych i ponadgimnazjalnych, które objęły 3986 uczniów województwa śląskiego. Młodzież ta była pytana także o autoidentyfikację narodowo-etniczną: 45,1\% badanej młodzieży uważa się za Polaków, 42\% za Polaków i Ślązaków, 6,5\% za Ślązaków, 1,4\% za Niemców i Ślązaków. Badaniami objęto szkoły zarówno w powiatach śląskich, jak i nieśląskich.

12 W 1995 r. ukazał się raport z badań Perspektywy stosunków polsko-niemieckich w opinii mieszkańców województwa katowickiego. Szanse i zagrożenia. W badaniach tych padło pytanie o samoidentyfikację respondentów. Pytani czuli się w większości przypadków Polakami - 66,5\% i Ślązakami - 25,7\%. Niemcami czuło się 5,8\% respondentów, zaś kategorie: Ślązak + Polak i Ślązak + Niemiec wybrało odpowiednio 0,5\% i 0,4\% badanych (Bartoszek i Gruszczyński 1995: 13). Z kolei w badaniach z 1996 r., dotyczących rozwoju społecznego, postawione zostało pytanie otwarte: „Kim się Pan/Pani czuje - Ślązakiem, Polakiem, Niemcem, kimś innym?”. Wynik raportu autorzy określili mianem samoidentyfikacji etniczno-regionalnej. Badani czuli się w większości przypadków Polakami - 63,8\%, Polakami i Ślązakami - 18,1\%, Ślązakami - 12,4\%, Niemcami i Ślązakami - 2,4\%, Niemcami - 1,1\% (Bartoszek i Gruszczyński 1995: 21). Podobnie kształtowały się wyniki badań prowadzonych przez inne zespoły badawcze. 
Opcja polska dominuje w szkołach znajdujących się w nieśląskich powiatach $(68,4 \%)^{13}$. Roczniki te w trakcie przeprowadzania kolejnego spisu powszechnego były już w sporej części osobami pełnoletnimi.

Z kolei rok wcześniej, bo w 2007 r., przeprowadzone zostały pod kierunkiem Marka S. Szczepańskiego badania, w których poruszono między innymi kwestię samoidentyfikacji Górnoślązaków. Większość respondentów na pytanie o samoidentyfikację stwierdziła, że czuje się w kolejności - Polakami (70,9\%), Ślązakami (16,8\%), Ślązakami opcji polskiej (9,6\%), Ślązakami opcji niemieckiej (0,9\%), Niemcami (0,5\%), kimś innym (1,1\%) osób badanych. W czasie tych badań zadane zostało pytanie o deklarowaną w czasie spisu w roku 2002 narodowość i zdecydowana większość - 86,1\% - deklarowała wówczas narodowość polską, a 13\% śląską. Pojawiły się również odniesienia do kategorii mieszanych. Gdyby spis odbywał się w drugiej połowie 2007 r., narodowość polską z tego grona osób zadeklarowałoby 82,2\%, śląską zaś - 15,4\%.

Pamiętać jednak należy, że wielu Górnoślązaków mieszka poza miejscem pochodzenia: zarówno w innych regionach Polski, jak i na emigracji, zwłaszcza - co zostało już wcześniej wspomniane - w Niemczech, dokąd wyjechali po II wojnie światowej w różnych falach migracyjnych. Masowe wyjazdy z Górnego Śląska miały miejsce zwłaszcza po podpisaniu w 1970 r. układu normalizacyjnego między RFN a PRL. Wyjazdy ludności rodzimej ze względu na skalę zjawiska zmieniły strukturę województwa śląskiego i opolskiego. Nadal bez dokładnej odpowiedzi pozostaje pytanie o dokładną liczbę Gómoślązaków, którzy wyjechali do Niemiec i uzyskali status „wysiedleńca” (Aussiedler). Zgodnie z ustaleniami na podstawie urzędowych statystyk niemieckiego historyka Joachima Rogalla w latach 1950-1993 ze Śląska do RFN przybyło 581449 osób (Wanatowicz 2004: 104). Natomiast Krystian Heffner podaje, że w latach 1988-2004 z historycznego obszaru Górnego Śląska wyjechało ponad 190000 osób, natomiast wróciło w tym okresie prawie 20000 osób (Heffner 2006: 108).W latach dziewięćdziesiątych na poziomie 50000 osób utrzymywała się z kolei tzw. emigracja zawieszona, obejmująca osoby, które były zameldowane na terenie województwa śląskiego i opolskiego, ale przebywały za granicą powyżej trzech miesięcy (Heffner 2006: 108). Dane te trzeba widzieć na tle statystyk niemieckich, podających skalę migracji z terenu całej Polski na podstawie dokumentów dających prawo

${ }^{13}$ Wyniki badań zostały omówione w wydanej w 2009 r. książce autorstwa Adama Bartoszka, Tomasza Nawrockiego i Justyny Kijonki-Niezabitowskiej Tożsamość młodych Ślqzaków. Między patriotyzmem lokalnym a europejskościq. 
do niemieckiego obywatelstwa. I tak w latach 1950-1979 wyemigrowało 605 510 osób, w latach zaś 1980-1994 kolejne 832414 osób. Już z tego zestawienia widać, ze większość „wysiedleńców” miała górnośląskie korzenie. Zgodnie z wyliczeniami Jana Korbla spośród 550000 emigrantów, którzy wyjechali w latach 1952-1980, około 400000 (70\%) to osoby zweryfikowane po wojnie jako rodzimi Polacy - głównie z Górnego Śląska (Korbel: 1986).

To, że w gronie wyjeżdżających z Polski po 1950 r. przeważały osoby pochodzące z Górnego Śląska, dowodzą także badania niemieckie przeprowadzone w 1976 r. na reprezentatywnej próbie „wysiedleńców”. Wyniki badań ukazały się w dwutomowej publikacji Die Aussiedler in der Bundesrepublik Deutschland. Autorzy opracowania przytaczają statystyki, według których między 1951 a 1975 rokiem na 476700 osób aż 209800 pochodziło - na podstawie miejsca urodzenia - z Górnego Śląska. Mowa tu jednak o granicach Polski z 1937 r. W badaniach ujmowani są również ci, którzy wyjechali z niemieckiego w okresie międzywojennym Górnego Śląska. Próba była reprezentatywna, a więc można przyjąć, że konsekwentnie i najwięcej badanych pochodziło z Górnego Śląska. Co istotne, zdecydowana większość pochodziła z niemieckiej przed wojną jego części. Należy podkreślić, że autorzy opracowania badali wysiedleńców z różnych krajów, w tym z Polski.

Wyjazdy Górnoślązaków do Niemiec po 1970 r. odbywały się zarówno na podstawie oficjalnych wniosków wyjazdowych, jak i wiz turystycznych oraz tranzytowych lub na zaproszenie. W pierwszym przypadku zazwyczaj emigrowała cała rodzina. Jednak ta forma wyjazdu związana była z wieloletnimi nieraz staraniami o wyjazd oraz represjami w pracy i w szkole. Dlatego też decydowano się częściej na wyjazd na podstawie wiz turystycznych lub zaproszeń. Zabierano (przemycano) wtedy ze sobą wszystkie potrzebne dokumenty i już w Niemczech Zachodnich załatwiano wszelkie formalności związane z otrzymaniem niemieckiego obywatelstwa. Wyjazd na podstawie wiz turystycznych czy na zaproszenie często skutkował rozbijaniem rodzin - współmałżonek lub dzieci zostawały w kraju w charakterze swoistej kaucji, nie zawsze bowiem cała rodzina otrzymywała paszporty. W początkowym okresie - zwykle legalnie - wyjeżdżała ludność znająca język niemiecki, nierzadko urodzona i socjalizowana jeszcze na niemieckim Górnym Śląsku. W kolejnych latach proporcje ulegają zmianie i emigrują roczniki coraz młodsze, które przeszły socjalizację w polskiej szkole. Dokumenty po przodkach dające obywatelstwo niemieckie na preferencyjnych zasadach wykorzystywane były jako bilet do zachodniego świata. Na te kwestie zwrócił uwagę w swojej monografii Christoph Pallaske (2002). 
Zmiana sposobu wyjazdu oraz fakt, że migrować zaczęły roczniki urodzone już w powojennej Polsce, nie zmieniły jednej ważnej rzeczy - wyjeżdżali głównie Górnoślązacy, i to ta grupa doczekała się największej liczby prac poświęconych „wysiedleńcom” z Polski ${ }^{14}$.

Jak już wspomniano, wyjazdy Górnoślązaków wpłynęły w sposób znaczący na strukturę ludności w województwie śląskim i opolskim. Wyniki badań z 2008 r., w ramach wspomnianego już projektu „Ja Ślązak, ja Polak, ja Europejczyk”, pokazują to wyraźnie: 12,8\% uczniów miało w Niemczech najbliższych (rodzeństwo, rodziców, dziadków), 56,7\% dalszą rodzinę (ciocie, wujków, kuzynostwo), zaś 40,7\% znajomych, z którymi utrzymywało kontakty. To ważne dane, wskazują bowiem na to, jak wielu Górnoślązaków ma rodzinę w Niemczech. Pamiętać trzeba, że ci, którzy wyjechali, ściągali także swoich bliskich. To cecha charakterystyczna tej właśnie migracji z Polski, że Górnoślązacy migrowali często „do kogoś”, zwykle do rodziny, która wyjechała wcześniej. W związku z tym, że górnośląskie rodziny mieszkają po obu stronach granicy, nasuwa się pytanie o to, jak kształtuje się górnośląska tożsamość w Polsce i w Niemczech. Czy są jakieś analogie, jakie są różnice? A więc co łączy, a co dzieli Górnoślązaków w Polsce i w Niemczech?

\section{Tożsamość górnośląskiej wspólnoty wyobrażonej}

W przypadku grup etnicznych takich jak Ślązacy uzasadnione jest mówienie o nich w kontekście koncepcji wspólnoty wyobrażonej Benedicta Andersona, który skonstruował - jak sam to określił - antropologiczną definicję naro$\mathrm{du}^{15}$. Jednak w rozważaniach dotyczących tożsamości górnośląskiej zarówno

${ }^{14}$ Warto zwrócić w tym kontekście uwagę na prace najnowsze: Ewy Palengi-Möllenbeck, Pendlemigration aus Oberschlesien. Lebensgeschichten in einer transnationalen Region Europas (2014), podejmującej w swej refleksji problem pokrewny, jednak pewną część narratorów autorki stanowią Górnośląscy „wysiedleńcy”, oraz Mariusa Otto, Zwischen lokaler Integration und regionaler Zugehörigkeit. Transnantionale Sozialräume oberschlesiensstämiger Aussiedler in Nordrhein-Westfalen (2015).

15 „[Naród] jest to wyobrażona wspólnota polityczna, wyobrażona jako nieuchronnie ograniczona i suwerenna. Jest ona wyobrażona, gdyż nawet przedstawiciele najmniej licznego narodu nie znają się w większości nawzajem. [...] Narody wyobrażane są jako wspólnoty ograniczone, ponieważ nawet największe z nich, liczące nawet miliard żywych istot ludzkich, zajmują skończony, choćby i rozciągliwy obszar, poza którym żyją inne narody. Żaden naród nie wyobraża sobie siebie jako całej ludzkości. [...] Narody wyobrażane są jako wspólnoty suwerenne, ponieważ pojęcie to powstało w czasach, kiedy Oświecenie 
w Polsce, jak i w Niemczech należy zaznaczyć, że mamy do czynienia raczej z grupą etniczną, lub też narodowością w rozumieniu na przykład Józefa Obrębskiego $^{16}$, niż z dojrzałym narodem czy wspólnotą o charakterze politycznym. Dokładna analiza rozważań Andersona pozwala odnieść wiele jego twierdzeń do Ślązaków, z zastrzeżeniem jednak, że nie są oni nadal wspólnotą o charakterze politycznym mimo istnienia organizacji śląskich o takim charakterze. Anderson podkreśla znaczenie w kształtowaniu się wspólnoty wyobrażonej kilku czynników narodotwórczych, które odnieść można także do Górnoślązaków. Mapa w przypadku górnośląskim to kwestia nie tylko terytorium. To również podziały pomiędzy państwa, to godła i symbole. Ktoś bowiem będzie wskazywał na orła piastowskiego, kto inny zaś przyjmie symbolikę Provinz Oberschlesien, i to bez względu na kraj zamieszkania. Ten ostatni symbol jest często stosowany jako element zaznaczenia swojej tożsamości poprzez flagi, naklejki na samochodach czy koszulki. Anderson zwraca też uwagę na rolę muzeów, pocztówek i reprodukcji. Funkcjonujące w społecznej świadomości jako śląskie, przemysłowe, a obecnie już postindustrialne krajobrazy są w różnych formach powielane, a nawet weszły nierzadko do pewnego kanonu śląskiej kultury, zwłaszcza tej popularnej. Miejsca pielgrzymowania, wymieniane przez Andersona - w przypadku jego teorii rozszerzone także na świeckie podróże - również mogą stać się pomocne w analizowaniu górnośląskiej tożsamości. Na Górnym Śląsku nie brak bowiem tradycyjnych miejsc pielgrzymowania, takich jak bazylika w Piekarach Śląskich. W Niemczech z kolei „wysiedleńcy” mają swoje pielgrzymki w ramach specjalnie dla nich utworzonego duszpasterstwa w obrębie niemieckiego Kościoła katolickiego. „Wysiedleńcy” uczestniczą także w pielgrzymkach organizowanych przez Polską Misję Katolicką.

i rewolucja podważyły legitymizacje uświęconych, hierarchicznych monarchii dynastycznych [...]. Rękojmią i symbolem tej wolności jest suwerenne państwo. [...] Wreszcie, naród wyobrażany jest jako wspólnota, ponieważ, mimo panujących w nim faktycznej nierówności i wyzysku, traktowany jest zawsze jako głęboki, poziomy układ solidarności” (Anderson 1997: 19-21).

${ }^{16}$ Jak pisał Obrębski, „pojęcie narodowości jest u socjologów rzeczą sporną. Podczas gdy u jednych teoretyków narodu - zwłaszcza dawniejszych - «naród» i «narodowość» są utożsamiane ze sobą i traktowane jako równoważniki, jako synonimy tego samego zjawiska, dziś przyjmuje się coraz bardziej utrzymywanie tego rozróżnienia i stosowanie tych dwóch terminów do różnych i wyraźnie rozgraniczanych przejawów zbiorowego życia narodowego. [...] Mówimy więc o narodzie polskim, żydowskim, łużyckim, ukraińskim itp., i jednocześnie o jednostkach tej narodowości. Równorzędnie jednak istnieją i inne ujęcia, według których za naród uważana jest grupa narodowa na szczycie swojego rozwoju, której przeciwstawiana jest narodowość jako niższy stopień ewolucji narodu” (Obrębski 2005: 180). 
W tym kontekście ważne jest nie tylko to, gdzie się pielgrzymuje, ale kim są inni pątnicy - czy są to „wysiedleńcy” identyfikujący się bardziej z niemieckością niż polskością, czy też jest to pielgrzymka Polskiej Misji Katolickiej. Warto w tym miejscu wspomnieć, że pielgrzymki na Górę św. Anny organizowane są przez Ziomkostwo Górnoślązaków, a więc organizację niemiecką. Ziomkostwo sprawuje również pieczę nad Muzeum Ziemi Górnośląskiej znajdujące się w Ratingen niedaleko Düsseldorfu.

Analizowane przez Andersona w kontekście rozważań o procesach narodotwórczych drukarstwo, jednoczesne czytanie gazet, powieści także jest przydatne w analizowaniu górnośląskiej tożsamości ponad granicami, choć należy wziąć pod uwagę również nowe formy medialne. Prowadzone obecnie analizy uwzględnić muszą zwłaszcza sferę kultury popularnej, w tym portale społecznościowe czy radia internetowe stanowiące nową przestrzeń dla manifestowania górnośląskiej tożsamości. Benedict Anderson w swych rozważaniach wiele uwagi poświęcił językowi, które to analizy rozpatrywać można także w odniesieniu do sporów dotyczących kodyfikacji gwary śląskiej. W przypadku Górnoślązaków mieszkających w Niemczech gwara śląska będzie ważnym narzędziem komunikacji, a druga generacja migrantów kojarzyć ją będzie z polszczyzną. Nie można w tym kontekście pominąć również tak zwanego urzędowego nacjonalizmu, o którym pisze amerykański historyk. W przypadku Górnego Śląska - monarchia Habsburgów czy Bismarckowskie Prusy to organizmy państwowe, których częścią był Górny Śląsk. A konsekwencje polityki prowadzonej przez oba państwa odegrały znaczącą rolę w kształtowaniu się górnośląskiej tożsamości.

Analizując przypadek górnośląski „ponad granicami”, pamiętać należy, że ci, którzy zdecydowali się na wyjazd na tak zwanych „niemieckich papierach”, żyją od lat w nieco innych światach społecznych niż ci, którzy pozostali w swej małej ojczyźnie. Co jednak jest charakterystyczne dla wyjazdów Górnoślązaków do Niemiec za pracą, czy też - jak w przypadku „wysiedleńców” - na pobyt stały, to geograficznie stosunkowo niewielka odległość między miejscem pochodzenia a miejscem zamieszkania w Niemczech. Odległość tę pokonywało się samochodem, zazwyczaj w ciągu jednego dnia mimo braku autostrad w Polsce i nie najlepszych dróg w Niemczech Wschodnich. Obecnie podróż ta jest łatwiejsza poprzez rozbudowę dróg w Polsce i w dawnych landach wschodnich. Na ów brak znaczącej odległości Niemiec Zachodnich od Górnego Śląska zwracała uwagę w swym studium o migracjach wahadłowych z Górnego Śląska do Niemiec Ewa Palenga-Möllenbeck (2014: 349). Pod tym względem sytuacja Górnoślązaków 
w Niemczech jest wyjątkowa, większość bowiem migracji opisywanych w kategorii nośnej obecnie teorii transnarodowej dotyczy migracji na duże w sensie geograficznym odległości, co zmusza migrantów do budowania swojego życia w większym stopniu w nowym miejscu (Palenga-Möllenbeck 2014: 349). Oczywiście, należy brać pod uwagę, że wyjazdy do Niemiec przed rokiem 1989 z definicji były wyjazdami na stałe, na zawsze, bez możliwości powrotu.

W przypadku Górnoślązaków mieszkających w Niemczech ta niewielka stosunkowo odległość sprzyjała, pomimo emigracji, utrzymywaniu osobistych kontaktów z rodziną i znajomymi, którzy zostali w Polsce. Jednak samo utrzymywanie kontaktów listownych czy telefonicznych, a nawet osobistych, wysyłanie paczek, transfery finansowe czy wzajemne odwiedziny nie są w kontekście migracji zjawiskiem nowym. Także nie jest nadal i nie było niczym wyjątkowym w przeszłości to, że korespondencja i kontakty z emigrantami zachęcały innych do wyjazdu. To stały element migracji o charakterze łańcuchowym. Co istotne, częstotliwość tamtych kontaktów i ich rodzaj miały inny charakter niż kontakty, które są utrzymywane obecnie. Wówczas dominowały kontakty korespondencyjne poprzez listy, natomiast później, gdy nastąpiło otwarcie granic, możliwe stały się częste wzajemne odwiedziny. Kontakt telefoniczny, początkowo utrudniony, także stanowił i stanowi ważny element kontaktów z rodziną, która została w Polsce. Nowe możliwości, jakie dają portale społecznościowe, Skype, aplikacje takie jak WhatsApp czy Viber sprawiają, że kontakty z miejscem pochodzenia zmieniły swój charakter i częstotliwość. Powstanie tanich linii lotniczych z kolei zrewolucjonizowało kontakty osobiste. Już nie trzeba jechać wiele godzin samochodem czy autobusem, dziś wystarczy wykupić odpowiednio wcześnie lot z Dortmundu czy Hahn do Pyrzowic, by znaleźć się szybko i za stosunkowo niewielkie pieniądze w Polsce. Świat się skurczył. Kolejne generacje uczą się języka polskiego poprzez maile i czaty z rówieśnikami z Polski. To także motywuje do nauki języka rodziców, stąd zdarzają się powroty do języka przodków. Jednak nastąpiło - co także jest naturalnym zjawiskiem - rozluźnienie więzi z regionem czy krajem pochodzenia rodziców i dziadków. Mimo rozluźnienia więzi kontakty utrzymywane z rodziną są nadal żywe, skoro w przytaczanych przeze mnie badaniach nad górnośląską młodzieżą znaczący odsetek miał bliskich i znajomych w Niemczech - znajomych ważnych, takich, z którymi utrzymywał kontakty. Pamiętać należy, że często rodzina, która wyjechała jako „wysiedleńcy”, to swoisty „punkt zaczepienia” dla tych, którzy współcześnie decydują się na emigrację zarobkową do Niemiec. 
Obecnie mówi się częściej o transnarodowości ${ }^{17} \mathrm{~W}$ odniesieniu do społeczności emigrantów, choć oczywiście nie wszyscy spełniają jej kryteria. W przypadku badań nad Górnoślązakami w Niemczech ta perspektywa także jest przez badaczy stosowana, choć można poddać ją krytyce. Analizując wywiady z górnośląskimi emigrantami w Niemczech, dostrzec można to, co nazywa się „Świadomością diasporyczną” charakteryzującą się podwójną lub wieloraką identyfikacją (Vertovec 2012: 6). Obejmuje ona wiele elementów zakorzenienia, bycia jednocześnie na emigracji i w regionie pochodzenia, bycia Polakiem, Ślązakiem i obywatelem niemieckim. Dlatego też koncepcja ta ma, niewątpliwie, zastosowanie w przypadku analizy tożsamości Górnoślązaków mieszkających na stałe w Niemczech. Wspomniana niewielka odległość między Górnym Śląskiem a Niemcami sprawia pewne problemy w bezkrytycznym zastosowaniu teorii transnarodowej. W tym przypadku zasadne są wątpliwości i potrzebna jest analiza - zaproponowana przez Stevena Vertoveca - tego, co stare, oraz tego, co nowe, czyli transnarodowe w zachowaniu migrantów (Vertovec 2012: 15-16). W przypadku Górnoślązaków w Niemczech będą to choćby formy komunikacji, jaką są radia internetowe, czy zmiana kontaktów rodzinnych poprzez nowe technologie. Jednak owa „transnarodowość” i nowe możliwości pojawiły się w momencie, gdy więzi rodzinne między tymi, którzy zostali, a tymi, którzy wyjechali, rozluźniły się. Drugie pokolenie Górnoślązaków w Niemczech nie zawsze jest w stanie porozumieć się ze względu na brak znajomości języka polskiego lub gwary śląskiej z rodziną, która pozostała na Górnym Śląsku. Młode pokolenie jest już bardziej w Niemczech niż w Polsce, choć nierzadko ważna jest dla nich świadomość innych niż niemieckie korzeni, co w dzisiejszych Niemczech traktowane jest w sposób naturalny. Nie oznacza to jednak, że kolejne generacje, urodzone już w Niemczech, nie wracają do kraju przodków w formie symbolicznej - poprzez język, wyjazdy do Polski w ramach programów wymiany studenckiej lub wręcz w celu odbycia całych studiów w Polsce.

Analizując kwestie tożsamości Górnoślązaków, warto zwrócić uwagę na pojęcie tożsamości kulturowej, o której Wojciech Świątkiewicz (1991: 10) pisze, że „powinna być ujmowana jako rzeczywistość istniejąca w świadomości ludzi, którzy w tej rzeczywistości uczestniczą i którzy ją tworzą, a socjologiczne badania nad tożsamością kulturową muszą odwoływać się do analizy działań społecznych podejmowanych przez człowieka”. Dalej zaś tak uzasadnia swoje stanowisko: „Tożsamość kulturowa oznacza, że całość,

${ }^{17}$ O problemach i kontrowersjach związanych z pojęciem transnarodowości piszą między innymi Steven Vertovec (2012) oraz Stephen Castles i Mark J. Miller (2011). 
którą nazywamy społeczeństwem, może się rozciągać tylko w takich granicach, w jakich istnieje zasadnicza jedność społecznej symboliki; znaczenia i wartości, jakie działający ludzie nadają pełnionym przez siebie czynnościom, są przez innych ludzi uświadamiane i rozumiane" (Świątkiewicz 1991: 12). Aleksandra Kunce z kolei stwierdza (tu przytoczę nieco dłuższy cytat), że „tożsamość kulturowa to wiedza o sobie, swoich, obcych budowana w trakcie trwania w określonej czasoprzestrzeni. Mamy różne składowe: swój wizerunek siebie jako siebie wśród swoich i wobec obcych, wizerunek swoich jako swoich, wizerunek tych obcych nam i mnie, wizerunki innych formujących społecznego mnie w odniesieniu do swoich, obcych. To mentalne tropy, które są dla nas i dla nich oczywiste, pierwsze, powtarzalne, trwałe. To wreszcie ciąg doświadczeń wspólnych nam i innym, które utrwalają zachowaniowe standardy. To zdarzenia, które musimy na mocy kulturowej konwencji odebrać jako właśnie te, które miały się zdarzyć, by potwierdzić, by zaprzeczyć, czyli - jednym słowem - by formować naszą wiedzę tożsamościową. Kim i czym jestem? Jak jestem? Pośród kogo i czego? Jak silna i w jakim stopniu konieczna jest nasza więź?” (Kunce 2007: 151).

Wspomniane pojęcie tożsamości kulturowej jest niezwykle przydatne w przypadku analizy tożsamości i jej komponentów Górnoślązaków mieszkających zarówno w Polsce, jak i w Niemczech, pewne bowiem elementy należące do sfery kultury będą tym, do czego odwołują się Górnoślązacy, mówiąc o swojej tożsamości i odrębności. To jest istotna wiedza o sobie samym, o swojej grupie, to wreszcie wizerunek siebie jako członka grupy odrębnej w pewnym sensie kulturowo od ,innych”, którzy do tej grupy nie należą. W społecznej świadomości właśnie poprzez pewne kulturowe komponenty Ślązacy postrzegani są jako „inni”, także w Niemczech. Polscy emigranci w Niemczech będą Górnoślązaków właśnie jako „nieco innych” postrzegać. Górnoślązacy także będą widzieli pewne różnice między sobą a tymi, którzy w tym samym czasie wyemigrowali z Polski do Niemiec.

\section{Kategorie tożsamości}

Analizując materiał empiryczny zebrany podczas badań w Polsce i w Niemczech, a składający się przede wszystkim z wywiadów swobodnych, można zauważyć pewne cechy wspólne Górnoślązaków mieszkających w obu krajach. Można także pokusić się o próbę ich kategoryzacji. I taką autorską próbę kategoryzacji chciałabym zaproponować. Dotyczy ona w większym stopniu Górnośląskich „wysiedleńców”. Polskie badania stanowią swego rodzaju tło, punkt odniesienia do komentowania kategorii. W przypadku tożsamości 
mamy do czynienia z jednej strony z pewnym kontinuum tożsamościowym: homogeniczni - transnarodowi, z drugiej z kontinuum tożsamości wzmacnianej - odwróconej. Jest także całe spektrum stosunku do Polski i polskości - od antypolskości do propolskości.

Hom ogeniczni pod względem tożsamościowym to Górnoślązacy mający jasno sprecyzowaną wizję siebie, tego, kim są i kim się czują. To osoby, które będą o sobie mówiły, że są Ślązakami, Polakami, Niemcami. W tej kategorii można umieścić także pewną subkategorię tożsamości nieco bardziej złożonej, składającej się zazwyczaj z dwóch komponentów - narodowego i etnicznego/regionalnego. To Górnoślązacy mający tożsamość podwójną, ale jasno zakreśloną, bez wątpliwości, kim są - to osoby, które powiedză, że są Ślązakami i Polakami lub Ślązakami i Niemcami jednocześnie. Nie będzie w tych autoidentyfikacjach wahania, konfliktu tożsamości. W przypadku tożsamości polskiej w Niemczech zdarza się, że jest ona bardzo wyrazista i silna - jak w przypadku jednej z respondentek, która nie przyjęła obywatelstwa niemieckiego i uważa się za Polkę w Niemczech. To jednak sytuacja wyjątkowa, rzadka.

Kontinuum ma to do siebie, że pomiędzy dwiema skrajnymi postaciami autoidentyfikacji zawiera się całe spektrum postaw. Są rozmówcy o tożsamości złożonej, którzy nie mają wątpliwości co do tego, kim są. Mieszczą się oni w kategorii „homogenicznych”. Jednak tożsamość złożona pojawia się zwykle po to, by podkreślać splątane korzenie własnej rodziny. Tu może występować pewnego rodzaju konflikt, poszukiwanie siebie samego, próba odpowiedzi na pytanie o to, kim się jest. Ci rozmówcy będą podkreślać w konsekwencji kilka filarów swojej tożsamości. To Ślązacy/Górnoślązacy Polacy i Ślązacy/Górnoślązacy - Niemcy, ale także polscy Niemcy i Niemcy z polskimi korzeniami. Tu pojawiają się różne warianty, a więc również takie określenia jak „polski Niemiec”, sugerujące pewne tożsamościowe zagubienie. Nie jest się w tym przypadku ani Polakiem, ani Niemcem. Korzenie ma się wprawdzie niemieckie, ale wychowanie i język są polskie. Dla Polaków nie jest się dość polskim, dla Niemców - dość niemieckim. To także sytuacja, gdy ktoś należy już do nowego kontekstu tak mocno, że to, co wiązało go z krajem pochodzenia, zanika. Nie jest się ani tu, ani tam. Z kolei rozmówcy bez autoidentyfikacji spotykani w Niemczech to osoby o splątanych korzeniach rodzinnych i bolesnej pamięci. Takie osoby często mówią o sobie, że są Europejczykami.

Europejczykami mogą być w przypadku Górnoślązaków w Niemczech także kosmopolici/transnarodowi. To często przedstawiciele drugiej generacji migrantów, osoby, które swobodnie przeskakują między kodem 
polskim i niemieckim, ale nie tylko. Mogą zaliczać się do tej grupy rozmówcy, którzy mają wprawdzie jasno określoną tożsamość, ale w ich przypadku kraj zamieszkania nie ma większego znaczenia. To, że wyemigrowali do Niemiec, jest dziełem przypadku. To obywatele świata dzięki swojej mentalności, osobowości, a także wykształceniu i znajomości języków obcych dających możliwość pracy na całym świecie. Ta kategoria częściej spotykana była podczas badań w Niemczech, choć i w Polsce można znaleźć osoby zaliczające się do jej przedstawicieli. W ich jednak przypadku ów kosmopolityzm czy transnarodowość mają nieco inny charakter.

W przypadku tożsamości zauważyć można kolejne dwie kategorie: tożsamości wzmacnianej i odwróconej. To kategorie widoczne w analizie materiału zarówno w Polsce, jak i w Niemczech. Wzmacnianie tożsamości ma miejsce podczas spotkania z „innymi”, które uświadamia jednostce jeszcze silniej jej pochodzenie. W przypadku badań w Polsce rozmówcy opowiadali o spotkaniach - najczęściej w okresie wakacyjnym - z mieszkańcami innych regionów Polski. Dostrzegali oni wtedy jeszcze silniej swą kulturową odrębność. Te spotkania uświadamiały im jeszcze dobitniej, że są Ślązakami. Miały one różny charakter i przebieg, były spotkaniami miłymi albo stanowiącymi - zwłaszcza w okresie PRL-u - przyczynę nieprzyjemności. Wzmacnianie zwłaszcza tożsamości śląskiej miało miejsce także w szkole, gdzie obowiązywał zakaz posługiwania się gwarą śląską.

W przypadku Górnoślązaków w Niemczech wzmacnianie tożsamości zachodziło, gdy rozmówca uważał się za Polaka lub Górnoślązaka i poprzez kontakt z Niemcami, a także innymi emigrantami z Górnego Śląska czy z innych części kraju, potwierdzał swą autoidentyfikację. Odbiór jego osoby był zgodny z tym, jak on sam siebie postrzegał.

Inaczej rzecz ma się z emigrantami, którzy mieszkając w Polsce, uważali się za Niemców lub niemieckich Ślązaków. Zetknięcie się z państwem niemieckim i samymi Niemcami powodowało, że przedstawiciele starszych generacji czuli się w nowym kraju obco - Niemcy po przemianach 1968 r. były innym krajem, niż mieli oni w pamięci. Górnoślązacy byli do tego bardziej tradycjonalistyczni i konserwatywni (Grabe 2000). W pewnym sensie nie pasowali do tego nowego niemieckiego społeczeństwa. „Wysiedleńcy” ze starszych roczników, dla których niemiecki był językiem ojczystym, mówili nierzadko nieco innym niemieckim, choć w tym przypadku ma to mniejsze znaczenie, bowiem z zasady Niemcy używają dialektów, powszechnie słyszy się różne akcenty. Odwrócenie tożsamości polegało na tym, że w zetknięciu z Niemcami zaczęli odczuwać większą więź z Polską mimo wcześniejszej niemieckiej identyfikacji. Odwrócona tożsamość jest widoczna, gdy mowa 
o Górnoślązakach w Polsce poszukujących swej tożsamości. Tak było w przypadku młodych Górnoślązaków, którzy brali udział w spotkaniach organizacji mniejszości niemieckiej. Organizacje te nie dały im tego, czego szukali, nie potwierdziły ich tożsamości, dlatego wybrali oni Młodzież Górnośląską lub Ruch Autonomii Śląska, gdzie ich śląskość znalazła potwierdzenie.

Istotną rolę odgrywa także kwestia nastawienia do polskości - propolska lub antypolska. Można więc być „Niemcem z nastawieniem propolskim wybiórczym”, jak to określił jeden z rozmówców, uważany w swoim środowisku powszechnie za Polaka. W przypadku rozmówców po obu stronach granicy antypolskość wynika z rozczarowania państwem polskim, wiąże się z poczuciem krzywdy za doznaną niesprawiedliwość bądź poczuciem ponoszenia kary za nie swoje winy - gdy mowa o osobach o silnej niemieckiej tożsamości ze starszych roczników. To zawsze bardzo subiektywne opinie, wiążące się nierzadko z rodzinnymi tragediami. Dochodzi tu często do zanegowania polskich korzeni i związków z polskością. Propolskość z kolei może przejawiać się w działalności w organizacjach polonijnych, w nauczaniu języka polskiego i w walce o jego certyfikację, wreszcie w dążeniu do przyznania Polakom statusu mniejszości. Obie postawy można, oczywiście, zaobserwować także w Polsce wśród działaczy organizacji regionalnych. Postawę antypolską, rozumianą jako pewnego rodzaju metaforę, można również odnaleźć we wszelkiego rodzaju postawach krytycznych wobec polityki państwa polskiego w stosunku do mniejszości etnicznych. Dotyczy to zarówno przeszłości, jak i czasu obecnego. Postawa ta daje o sobie znać na poziomie indywidualnym - konkretnych krzywd, których doznała jednostka, lub zbiorowym - traktowania Górnoślązaków przez państwo polskie jako obywateli drugiej kategorii ze wszystkimi tego konsekwencjami dla ludności rodzimej.

\section{Podsumowanie}

Górnoślązacy, opisując swoją tożsamość, która odnosi się do emocjonalnego związku z regionem, akcentują swoją wyjątkowość kulturową. W przypadku osób nastawionych krytycznie do tożsamości narodowej, czy wręcz poprzez swą śląskość odcinających się od jakiegokolwiek narodu, będzie przeważać argumentacja podkreślająca wręcz narodową odrębność Górnoślązaków. Z kolei ci, którzy oprócz tożsamości górnośląskiej podkreślać będą przywiązanie do Polski czy Niemiec, akcentować będą te elementy kultury śląskiej, które potwierdzają ich związki z jednym, bądź drugim krajem. Bez względu jednak na to, z jaką dominującą autoidentyfikacją będziemy mieć do czynienia, 
wszyscy moi rozmówcy zarówno w Polsce, jak i w Niemczech podkreślać będą związek z regionem, z którego się wywodzą. Jak zauważa Bohdan Jałowiecki, „na początku wszyscy jesteśmy lokalni w tym najbardziej dosłownym sensie tego słowa. Każdy człowiek rodzi się w jakimś miejscu i tam po raz pierwszy doświadcza świata, który wraz z dorastaniem rozszerza się coraz bardziej. Miejsce to określa nasza tożsamość, pozwala odpowiedzieć na pytanie, skąd przyszliśmy, kim jesteśmy. W ten sposób powstaje nasza pierwotna tożsamość, przynależność - jak pisał Stanisław Ossowski - do ojczyzny prywatnej. Wszystkie następne tożsamości, w tym poczucie przynależności narodowej, są wtórne i może być ich wiele” (Jałowiecki 2012: 15). Nie jest to w żadnym wypadku sytuacja trwała. Podlega ona zmianom pod wpływem nowych czynników i wpływów związanych z aktywnością w życiu społecznym. W tym kontekście tożsamość śląska zarówno w Polsce, jak i w Niemczech jest zjawiskiem podlegającym przemianom. Jest także zjawiskiem, które należy rozpatrywać w nawiązaniu do bogatej górnośląskiej kultury, do rozległej tradycji i wreszcie do przeszłości i historii, bo to one w zasadniczy sposób ukształtowały tożsamość mieszkańców tego regionu i rzutują nadal na identyfikację etniczną Górnoślązaków mieszkających po obu stronach granicy.

\section{Literatura}

Anderson B. (1997), Wspólnoty wyobrażone. Rozważania o źródłach i rozprzestrzenianiu się nacjonalizmu, Kraków: Społeczny Instytut Wydawniczy Znak; Warszawa: Fundacja im. Stefana Batorego.

Arnold W. (Hrsg.) (1985), Die Aussiedler in der Bundesrepublik Deutschland: Forschungen der AWR Deutsche Sektion, Band 1: Herkunft, Ausreise, Aufnahme, Wien: Braumüller.

Bartoszek A., Gruszczyński L.A. (1995), Perspektywy stosunków polsko-niemieckich w opinii mieszkańców województwa katowickiego: szanse i zagrożenia, Katowice: Ośrodek Badań Społeczno-Kulturowych Towarzystwa Zachęty Kultury.

Bartoszek A., Gruszczyński L.A. (1996), Województwo katowickie ‘96: obraz z życia i jego warunków w świadomości mieszkańców: raport o rozwoju społecznym, Katowice: Ośrodek Badań Społeczno-Kulturowych Towarzystwa Zachęty Kultury.

Bartoszek A., Nawrocki T., Kijonka-Niezabitowska J. (2009), Tożsamość młodych Ślqzaków. Między patriotyzmem lokalnym a europejskościq, Katowice: Fundacja dla Śląska.

Castles S., Miller M.J. (2011), Migracje we współczesnym świecie, Warszawa: Wydawnictwo Naukowe PWN.

Chałasiński J. (1935), Antagonizm polsko-niemiecki w osadzie fabrycznej „Kopalnia” na Górnym Ślq̨sku: studium socjologiczne, Warszawa: Dom Książki Polskiej.

Grabe W. (2000), Górnoślq̨scy „przesiedleńcy” w Niemczech, w: A. Wolff-Powęska, E. Schulz (red.), Być Polakiem w Niemczech, Poznań: Instytut Zachodni. 
Harmsen H. (Hrsg.) (1983), Die Aussiedler in der Bundesrepublik Deutschland: Forschungen der AWR Deutsche Sektion, Band 2: Anpassung, Umstellung, Eingliederung, Wien: Braumüller.

Heffner K. (2006), Migracje do Niemiec i polska polityka regionalna a ślq̨ska tożsamość, w: J. Janeczek, M.S. Szczepański (red.), Dynamika śląskiej tożsamości, Katowice: Wydawnictwo Uniwersytetu Śląskiego.

Jałowiecki B. (2012), Ślązacy o narodzie i tożsamości, w: E.A. Sekuła, B. Jałowiecki, P. Majewski, W. Żelazny (red.), Być narodem? Ślqzacy o Ślq̨sku, Warszawa: Wydawnictwo Naukowe Scholar.

Kersten K. (1986), Ruchliwość w Polsce po II wojnie światowej jako element przeobrażeń społecznych i kształtowania postaw, „Przegląd Historyczny” nr 77/4.

Kijonka J. (2013), Migracje z Górnego Ślq̨ska do Republiki Federalnej Niemiec w latach 1970-1989, czyli między ojczyznq prywatnq a ideologicznq, „Górnośląskie Studia Socjologiczne. Seria Nowa” t. 4.

Kijonka J. (2016), Tożsamość współczesnych Górnoślq̨zaków. Studium socjologiczne, Katowice Thesaurus Silesiae, Katowice: Wydawnictwo Naukowe Śląsk.

Kopeć E. (1986), „My i oni” na polskim Ślq̨sku (1918-1939), Katowice: Wydawnictwo Naukowe „Śląsk”.

Korbel J. (1977), Wyjazdy i powroty. Migracje ludności w procesie normalizacji stosunków między Polskq a RFN, Opole: Instytut Śląski w Opolu.

Korbel J. (1983), Emigracje z Polski do RFN. Wybrane problemy, Opole: Wyższa Szkoła Pedagogiczna im. Powstańców Śląskich w Opolu.

Korbel J. (1986), Emigranci z Polski do RFN w świetle statystyk i analiz (1952-1985), Opole: Wojewódzki Ośrodek Informacji Naukowej, Technicznej i Ekonomicznej.

Kunce A. (2007), Problemy tożsamościowej układanki. Puzzle gliwickie, w: A. Kunce, Z. Kadłubek (2007), Myśleć Ślq̨sk, Katowice: Wydawnictwo Uniwersytetu Śląskiego.

Kunce A., Kadłubek Z. (2007), Myśleć Ślq̨sk, Katowice: Wydawnictwo Uniwersytetu Śląskiego.

Łempiński Z. (1987), RFN wobec problemów ludnościowych w stosunkach z Polskq (1970-1985), Katowice: Śląski Instytut Naukowy.

Obrębski J. (2005), Dzisiejsi ludzie Polesia i inne eseje, Warszawa: Wydawnictwo IFiS PAN.

Ossowski S. (1984), O ojczyźnie i narodzie, Warszawa: PWN.

Otto M. (2015), Zwischen lokaler Integration und regionaler Zugehörigkeit. Transnantionale Sozialräume oberschlesiensstämiger Aussiedler in Nordrhein-Westfalen, Bielefeld: transcript Verlag.

Palenga-Möllenbeck E. (2014), Pendlemigration aus Oberschlesien. Lebensgeschichten in einer transnationalen Region Europas, Bielefeld: transcript Verlag.

Pallaske C. (2002), Migrationen aus Polen in die Bundesrepublik Deutschland in den 1980er und 1990er Jahren: Migrationsverläufe und Eingliederungsprozesse in sozialgeschichtlicher Perspektive, Berlin: Waxmann.

Rybicki P. (1938), O badaniu socjograficznym Ślq̨ska, Katowice: Instytut Śląski.

Sekuła E.A., Jałowiecki B., Majewski P., Żelazny W. (red.) (2012), Być narodem? Ślqzacy o Ślq̨sku, Warszawa: Wydawnictwo Naukowe Scholar.

Szczepański M.S. (2003), Inni swoi, http://www.tg.net.pl/indianer/==regionalizm_5.htm [23.04.2017]. 
Szczepański M.S., Zagała Z. (2009), Chaos oswojony? Województwo ślq̨skie i jego społeczne Metamorfozy, Katowice: Wydawnictwo Gnome.

Szmeja M. (2000), Niemcy? Polacy? Ślqzacy! Rodzimi mieszkańcy Opolszczyzny w świetle analiz socjologicznych, Kraków: Towarzystwo Autorów i Wydawców Prac Naukowych „Universitas”.

Szramek E. (1934), Ślq̨sk jako problem socjologiczny, Katowice: Roczniki Towarzystwa Przyjaciół Nauk na Śląsku.

Świątkiewicz W. (1991), Tożsamość kulturowa, w: W. Świątkiewicz, K. Wódz, Tożsamość kulturowa mieszkańców starych dzielnic miast Górnego Ślq̨ska, Wrocław i in.: Zakład Narodowy im. Ossolińskich.

Trzcielińska-Polus A. (1997), „Wysiedleńcy” z Polski w Republice Federalnej Niemiec w latach 1980-1990. Opole: Państwowy Instytut Naukowy - Instytut Śląski.

Vertovec S. (2012), Transnarodowość, Kraków: Wydawnictwo Uniwersytetu Jagiellońskiego.

Wanatowicz M.W. (2004), Od indyferentnej ludności do ślq̨skiej narodowości? Postawy narodowe ludności autochtonicznej Górnego Ślq̨ska w latach 1945-2003 w świadomości społecznej, Katowice: Wydawnictwo Uniwersytetu Śląskiego.

Wódz J. (2001), Prospektywna definicja regionu w odniesieniu do nowych polskich województw - szkic socjologiczny, w: M.S. Szczepański (red.), Jaki region? Jaka Polska? Jaka Europa? Studia i szkice socjologiczne, Katowice: Wydawnictwo Uniwersytetu Śląskiego. 